\title{
Detorgan-3índía:
}

Telaah Pemikiran Kebangsaan

Volume 3 No 1 Tahun 2021 HImn. 30 - 34

Artikel Masuk 10 Desember 2020 I Artikel Diterima 13 Desember 2021

\section{Akuntansi Antropologi: Ritus Pernikahan Jawa Dengan Pembukuan Untuk Nilai Kemasyarakatan}

\author{
Reza Ramadhania* \\ Universitas Brawijaya, Indonesia, 65145 \\ *reza.ramadhania@gmail.com
}

\begin{abstract}
Abstrak
Penelitian ini akan berfokus pada akuntansi antropologi pada ritus pernikahan adat jawa. Pernikahan adat jawa yang menggunakan sistem pembukuan untuk meningkatkan nilai kemasyarakatan. Istilah buwuhan muncul pada masyarakat adat jawa dalam ritus pernikahan. Tujuan penelitian ini yakni untuk mengetahui ritus pernikahan adat jawa dengan menggunakan sistem pembukuan untuk meningkatkan nilai kemasyarakatan. Pemilihan informan berdasarkan metode snow ball sampling dan metode pengumpulan data dari sumber data primer dan sekunder. Buwuhan menjadi tradisi masyarakat untuk memberi barang atau uang kepada orang yang memiliki acara pernikahan. Tujuannya tak lain untuk membantu atau meringankan beban orang yang memiliki acara tersebut.
\end{abstract}

Kata Kunci : Budaya, Pernikahan, Masyarakat

\begin{abstract}
This research will focus on anthropological accounting on Javanese traditional wedding rites. Javanese traditional marriage that uses a bookkeeping system to increase social value. The term buwuhan appears in Javanese indigenous peoples in marriage rites. The purpose of this study is to determine the Javanese traditional wedding rites by using a bookkeeping system to increase social value. The selection of informants was based on the snow ball sampling method and data collection methods from primary and secondary data sources. Buwuhan is a community tradition to give goods or money to people who have weddings. The goal is none other than to help or lighten the burden on the people who have the event.
\end{abstract}

Keywords : Culture, Marriage, Society
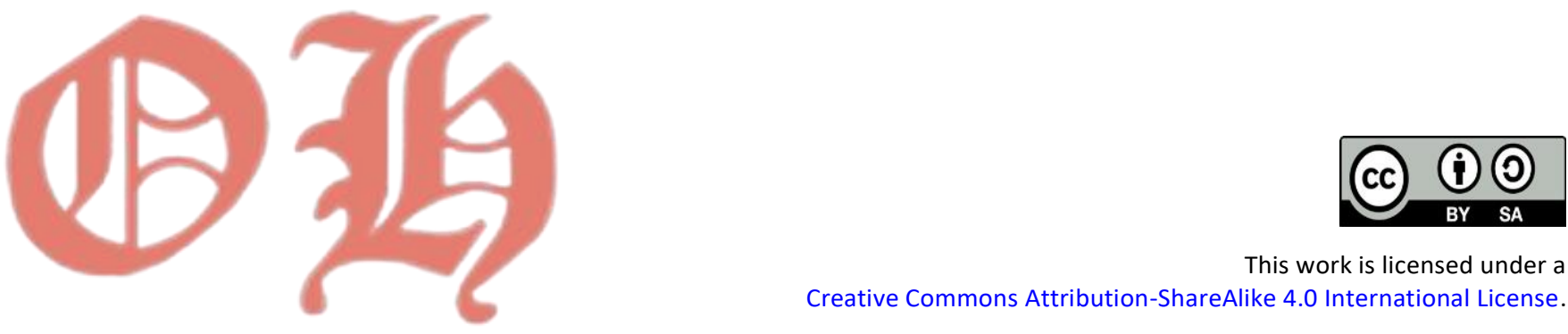


\section{Reza Ramadhania}

Penelitian ini berfokus pada akuntansi antropologi pada ritus pernikahan adat jawa. Pernikahan merupakan acara yang sakral dan ditunggu bagi setiap masyarakat. Seseorang akan mempersiapkan acaranya dari mulai awal hingga akhir dengan baik agar bisa dikenang. Dalam acara pernikahan memiliki perayaan yang sakral sesuai dengan adat dan budaya masyarakat sekitar (Murtiadji,1993). Dalam pernikahan adat jawa juga memiliki serangkaian ritual untuk mengisi acara pernikahan dan memiliki kesakralan budaya. Masyarakat adat jawa masih memegang budaya untuk melaksanakan upacara pernikahan meskipun dimodifikasi dengan adat luar.

Dalam penelitian Santoso (2017) dengan judul pola pengaturan transaksi sumbangan (buwuh) dalam adat perkawinan di Desa Mayong, Jepara. Tujuan penelitian untuk mengetahui dan mengidentifikasi alasan masyarakat, bentuk pola transaksi danakibat yang terjadi dalam tradisi nyumbang. Pelaksanaan tradisi nyumbang di Desa Mayong Lor tidak didasarkan pada akad yang jelas, hanya menggunakan akad lisan yang nanti di khawatirkan terjadi konflik sosial. Hasil penelitian menunjukkan bahwa masyarakat melakukan tradisi karena keharusan untuk memaknai warisan leluhur, mengurangi beban orang yang punya acara dan investasi sosial karena adanya resiprositas.

Fokus dari penelitian ini yakni pernikahan adat jawa yang menggunakan sistem pembukuan untuk meningkatkan nilai kemasyarakatan. Istilah buwuhan muncul pada masyarakat adat jawa dalam ritus pernikahan. Buwuhan menjadi tradisi masyarakat untuk memberi barang atau uang kepada orang yang memiliki acara pernikahan. Tujuannya tak lain untuk membantu atau meringankan beban orang yang memiliki acara tersebut. Barang yang dibawa pun beragam sesuai dengan kebutuhan pemilik acara seperti beras, gula, rokok dan kebutuhan pangan lainnya. Barang atau uang ini akan dicatat dalam sebuah buku khusus sesuai dengan jenis dan jumlahnya. Tujuan pembukuan ini untuk pengembalian barang atau uang dari orang yang mengadakan acara kepada orang pemberi dengan catatan orang pemberi mempunyai acara pernikahan juga. Barang atau uang dikembalikan sesuai dengan nilai yang dicatat dalam buku.

Menurut Polanyi (1968) resiprositas merupakan pertukaran timbal balik antarindividu atau antarekelompok. Polanyi memberi batasan resiprositas sebagai perpindahan barang atau jasa secara timbal balik dari kelompok-kelompok yang terhubung secara simetris. Hubungan simetris ini adalah hubungan sosial, di mana masing-masing pihak menempatkan diri dalam kedudukan dan peranan yang sama ketika proses penukaran berlangsung. berbeda dengan konsep resiprositas, konsep redistribusi sebaliknya. Aktivitas redistribusi memelurkan syarat adanya hubungan asimetris, yang ditandai oleh adanya peranan individu-individu tertentu dengan wewenang yang dimiliki ke dalam kelompok untuk mengorganisasir pengumpulan barang atau jasa dari anggotaanggota kelompok kemudian didistribusikan kembali ke kelompok tersebut dalam bantuk barang atau jasa yang sama atau berbeda. Tujuan penelitian ini yakni untuk mengetahui ritus pernikahan adat jawa dengan menggunakan sistem pembukuan untuk meningkatkan nilai kemasyarakatan. Penelitian ini menggunakan dua aspek ilmu yakni dari akuntansi dan antropologi sosial.

\section{Metode Penelitian}

Penelitian ini dilakukan pada masyarakat Desa Wonosari, Kabupaten Mojokerto. yang mana masyarakat masih menggunakan tradisi adat pernikahan menggunakan sistem pembukuan. Dalam penelitian ini, pemilihan informan berdasarkan metode snow ball sampling. Peneliti mencari informan atau narasumber yang benar-benar mengetahui dan mengerti proses serta materi penelitian sebagai informan kunci, yakni kepala adat. Dari informan kunci tersebut kemudian akan memberikan rekomendasi lainnya sebagai informan lain, sehingga peneliti memiliki banyak data yang akan digunakan sebagai rujukan, yakni masyarakat yang pernah menggunakan pernikahan dengan sistem pembukuan. Menurut Sugiyono (2012:137) menyatakan bahwa metode pengumpulan data yang dilakukan pada penelitian ini berasal dari sumber data primer dan sekunder. Metode primer dilakukan menggunakan etnografi dengan menggunakan teknik wawancara in depth interview. Kemudian data sekunder didapatkan dari dokumen foto, literatur, dan naskah dari penelitian serupa. 


\section{Hasil Dan Pembahasan}

Akuntansi memiliki istilah an everchanging discipline yang artinya ilmu ini akan memiliki perubahan sesuai dengan masanya. Hal ini dapat dilihat dari ilmu akuntansi yang semula hanya digunakan untuk pelaporan transaksi sebuah perusahaan, sekarang pemahamannya lebih luas (Arif,2012). Artinya ilmu akuntansi dapat dihubungkan dengan ilmu lain yang saling berkaitan sehingga pengetahuan tentang akuntansi semakin luas dan bermanfaat pada masyarakat.

Semakin luasnya ilmu pengetahuan maka dapat berguna pada kehidupan masyarakat. Seperti pada ilmu akuntansi yang awalnya hanya berguna hanya di seputar perusahaan untuk mencatat transaksi keuangan. Saat ini akuntansi bisa meluas kemasyarakat lainnya dari mulai masyarakat bawah hingga atas. Kemudian akuntansi saat ini tidak hanya dinilai dengan mata uang saja, melainkan juga barang dan jasa.

Menurut Mulawarman, dkk (2018) pendidikan akuntansi di Indonesia telah terbentuk dengan menerapkan akuntansi positif di pasar modal barat. Perkembangan ini semata-mata karena pendidikan para akademisi Indonesia di AS, yang telah menanamkan sentimen orientalis yang serupa terhadap akuntansi. Dalam antropologi, peran agen yang dikenal sebagai agen akulturasi dalam memperkenalkan dan menyebarkan budaya (dalam hal ini teknik akuntansi melalui IFRS) penting untuk menghasilkan kulturkreis. Sejarah kulturkreis akuntansi di Indonesia dimulai pada tahun 1973, ketika IAI mengadopsi standar akuntansi dari US GAAP (Prinsip Akuntansi yang Diterima Secara Umum) serta beberapa standar dari Australia (Pernyataan Prinsip Akuntansi Australia).

Pada tahun 2012, evolusi akuntansi yang berkelanjutan menuju akuntansi Barat terlihat dalam perjanjian oleh IAI untuk sepenuhnya mengadopsi dan menerapkan IFRS (Standar Pelaporan Keuangan Internasional). Salah satu tujuan IFRS adalah untuk mengembangkan satu set standar pelaporan keuangan internasional (IFRS) yang berkualitas tinggi, dapat dimengerti, dapat dilaksanakan dan diterima secara global melalui badan pengaturan standarnya, IASB (www.ifrs.org). Istilah dapat ditegakkan dan diterima secara global menunjukkan bahwa IFRS menjadi kulturkreis paksa agama atau keyakinan yang ditanam karena Barat menyusup ke standar akuntansi internasional dengan etika Protestannya.

Muncul akuntansi multiparadigma atau beberapa pemikiran tentang akuntansi menjadi meluas dan menambah ilmu pengetahuan terkait bidang akuntansi. Pada dasarnya pemikiran dalam dunia tidak satu dan memiliki perbedaan perspektif (Triyuwono, 1996). Perbedaan ini bisa membuat perpecahan, namun dalam bidang ilmu pengetahuan perbedaan bisa memperluas pola berfikir.

Akuntansi multiparadigma muncul dengan berbagai perspektif dan bidang keilmuan. Diantaranya yakni akuntansi antropolgi, akuntansi sosiologi, akuntansi politik, akuntansi agama dan lainnya. Fokus dari akuntansi multiparadigma ini untuk memperluas kajian ilmu akuntansi, memperluas pengetahuan akuntan dan masyarakat. Sehingga akuntansi pada

Dalam acara pernikahan terdapat bentuk resiprositas umum, di mana suatu individu atau kelompok memberikan barang atau jasa kepada individu atau kelompok lain tanpa menentukan batas waktu mengembalikan. sistem ini biasanya dilakukan di kalangan orang-orang yang mempunyai hubungan kerabat dekat. Barang yang sudah diberikan oleh suatu individu atau kelompok ini akan dicatat, agar pengembalian nya sesuai dengan apa yang diterima.

Nilai hidup bermasyarakat akan muncul dari tradisi adat yang diadakan oleh masyarakat sekitar. Semakin banyak tradisi maka nilai kekeluargaan dan kepemilikan akan semakin erat. Dalam menjalankan tradisi pernikahan akan muncul nilai simpati dan empati, sehingga masyarakat sekitar akan membantu orang yang mengadakan acara pernikahan.

ndonesia memiliki berbagai adat, budaya dan bahasa yang menjadikannya multikulturalisme. Keberagaman ini menjadi keunikan dan tantangan bagi masyarakat Indonesia untuk hidup berdampingan. Dengan adanya keragaman maka semakin banyak pula pengetahuan masyarakat tentang budaya dan adat.

Keragaman ini menjadi keunikan bagi peneliti untuk melakukan penelitian lebih dalam pada masyarakat adat. Fokus penelitian yakni pernikahan adat jawa yang menggunakan sistem pembukuan untuk mencatat utang-piutang. Dalam pernikahan adat jawa ada istilah buwuhan yang diartikan sebagai pemberian orang yang diundang dalam acara pernikahan dengan membawa uang, gula, beras atau jenis lainnya. Barang bawaan ini akan dicatat oleh orang yang mempunyai acara dengan pembukuan yang rapi. Tidak ada ketentuan barang apa yang dibawa untuk menghadiri 


\section{Reza Ramadhania}

acara. Apabila acara pernikahan sudah selesai buku akan disimpan dengan rapi dan digunakan sesuai kebutuhan. Arti dalam kebutuhan ini yakni apabila orang yang sudah mempunyai acara kemarin diundang oleh orang lain, maka orang tersebut membawa barang bawaan sesuai dengan pencatatan buku.

Sistem pemberian pada masyarakat adat jawa pada tradisi pernikahan ini diwariskan dari nenek moyangnya. Tujuannya untuk meringankan beban pada orang yang mempunyai acara karena mengeluarkan kebutuhan yang banyak.

"Orang yang punya hajat nikah pasti kebutuhannya banyak dari mulai beras, sayur, gula, dan lainnya. Masyarakat membantu dengan memberikan barang atau uang untuk membantu meringankan keperluan itu" (Pak Agus, Wawancara, 03 Desember 2020).

Pemberian yang diberikan oleh masyarakat untuk orang yang mempunyai acara pernikahan akan dicatat dalam pembukuan khusus. Pencatatan dilakukan oleh kerabat dari pemilik acara yang sudah dipercaya agar barang yang diberikan dicatat dengan sebenar-benarnya. Barang yang dibawa kemudian disimpan dalam ruangan khusus agar tersimpan dengan rapi. Setelah acara selesai pembukuan ini harus disimpan dengan rapi agar nanti bisa digunakan untuk memberi bantuan pada masyarakat lain yang membutuhkan.

Peneliti lebih lanjut meneliti pada sistem pembukuan untuk pengembalian barang pada pernikahan adat jawa. Mengapa pemberian tidak dinilai sebagai pemberian semata artinya tidak ada resiprositas. Karena zaman semakin berkembang dan nilai mata uang juga mengalami kenaikan. Apabila tujuannya untuk sistem keadilan lalu bagaimana dengan kenaikan nilai mata uang.

Pembukuan ini sangat penting bagi masyarakat jawa karena dari buku tersebut dapat dilihat kepedulian masyarakat. Dari pembukuan ini dapat membalas pemberian sesuai dengan barang atau uang yang sudah diberikan sebelumnya. Ada timbal balik yang terjadi pada masyarakat jawa terutama pada tradisi pernikahan.

"Buku ini penting untuk mengetahui siapa saja yang datang dan pemberian apa yang

dibawa. Disini sistemnya timbal balik, jadi tidak ada orang yang dirugikan. Niat

nenek moyang masyarakat jawa saling membantu meringankan beban” (Bu Indah,

Wawancara. 05 Desember 2020).

Pembukuan ini akan berguna bagi orang yang mempunyai acara untuk mengidentifikasi kerabat yang peduli dalam kehidupannya. Pemberian ini sangat berguna bagi orang yang memiliki acara karena dapat membantu serta meringankan beban kebutuhan. Saling membantu dan tolongmenolong menjadi prinsip masyarakat adat dalam menjalani kehidupan.

Misalnya si A membawa gula $3 \mathrm{~kg}$ di acara pernikahan si B, kemudian si B melakukan pencatatan dengan rapi dan baik. Ketika si A mempunyai acara pernikahan, maka si B membawa gula $3 \mathrm{~kg}$ sesuai dengan apa yang dibawa oleh si A. Peristiwa tersebut dinamakan dengan buwuhan dengan pengembalian utang-piutang. Apabila ditelaah lebih lanjut seseorang yang ingin memberi, maka cukup memberi dengan sukarela. Tidak perlu ada sistem pembukuan dalam acara pernikahan. Niat seseorang yang memberi ingin meringankan beban pada orang yang mempunyai acara sehingga kebutuhan untuk acara terpenuhi. Perlu diketahui bahwa si A bisa tidak mengembalikan barang yang sama dengan pemberian si B. Jika terjadi demikian maka nilai barangnya harus sama dan diakumulasikan dengan uang tunai.

Di sisi lain sistem pembukuan ini bisa membawa dampak positif bagi masyarakat adat jawa. Sistem pembukuan ini akan diketahui siapa saja yang datang untuk membantu acara pernikahan dan siapa yang tidak membantu tanpa adanya halangan. Sehingga pihak yang mengadakan acara mengetahui sifat orang tersebut kepada keluarganya. Apabila tidak datang tanpa adanya alasan yang logis maka orang tersebut telah mengabaikan keluarga yang mengadakan acara pernikahan. 


\section{Simpulan}

Pernikaham adat jawa menggunakan sistem pembukuan bagi masyarakat yang memberi barang atau uang. Pemberian ini dinilai untuk membantu meringankan beban orang yang mempunyai acara. Pemberian ini kemudian dicatat yang nantinya akan dikembalikan kepada orang pemberi sebelumnya apabila mengadakan acara pernikahan. Dapat dilihat bahwa nilai kepedulian masyarakat jawa tinggi karena ada kepekaan sosial dari tradisi pernikahan. Harapannya dari tradisi pernikahan ini yang saling membantu antarmasyarakat sehingga nilai kepekaan sosial tinggi. Penelitian ini belum membahas tentang hukum adat yang ada pada masyarakat apabila pemberian tidak dikembalikan. Hal ini bisa menjadi saran untuk penelitian sebelumnya untuk berfokus pada hukum adat masyarakat jawa pada tradisi pernikahan.

\section{Daftar Pustaka}

Hartono, Arif. 2012. Multiparadigma Dalam Penelitian Akuntansi: Suatu Tinjauan Konsep.

Mulawarman, Kamayanti. 2018. Toward Islamic Accounting Anthropology: How Secular Anthropology Reshaped Accounting in Indonesia. Emerald Insight.

Murtadji, Sri. 1993. Tata Rias Pengantin Gaya Yogyakarta.Yogyakarta: Gramedia Pustaka Utama

Polanyi, Karl. 1968. Societies and Economics System, dalam George Dalton. Primitive, Archaic, and Modern Economies, Easays of Karl Polanyi. Boston: Beacon Pers.

Santoso, Faizal. 2017. Pola Pengaturan Transaksi Sumbangan (Buwuh) Dalam Adat Perkawinan di Desa Mayong Lor, Kecamatan Mayong, Kabupaten Jepara. Semarang

Sugiyono. 2012. Metode Penelitian Kuantitatif Kualitatif dan R\&D. Bandung: Alfabeta Triyuwono, Iwan. 1996. Paradigma Metode Penelitian Akuntansi. Media Ekonomi. Vol.13 No.20,; 27 $-42$ 